\title{
SP011 wt Allele
}

National Cancer Institute

\section{Source}

National Cancer Institute. SPO11 wt Allele. NCI Thesaurus. Code C52269.

Human SPO11 wild-type allele is located within 20q13.2-q13.3 and is approximately $14 \mathrm{~kb}$ in length. This allele, which encodes meiotic recombination protein SPO11, plays a role in both meiotic recombination and chromosomal segregation. 